\title{
The Peculiar Policy of Recognition of Indigenous Laws in British Colonial Africa. A Preliminary Discussion
}

\author{
By Gordon R. Woodman
}

\section{Introduction}

The recognition by state law of an indigenous people's folk law is an important measure in the development of their culture. In understanding various issues, it may assist to study instances where recognition has been given. The historical experience of the former British African territories may afford insights into the implications of contemporary indigenous group's objectives, despite the obvious differences in circumstances.

The initial constitutional ordering of the British African colonies (including protectorates, protected states and mandanted territories 1 ) in the period from the 1870 s to the 1900 s included the establishment of judicial systems. British lawyers in government service in London were among the vital decisionmakers. The legislation which they drafted generally required the superior courts in each colony to apply English law, 2 but also to apply, or be guided by indigenous laws. ${ }^{3}$ Furthermore, their schemes preserved or established "native courts", which were to apply indigenous laws in most cases. 4 Thus at the inception of the British empire in Africa there were created by imperial decree plural systems of state laws, applying imported English law but also recognising indigenous customary laws, a type of system aspired to by many indigenous groups throughout the world today.

1 These constitutional forms will all be referred to as "colonies", since the distinctions between them were not significant for the present purpose: see e.g. Roberts-Wray, K.O., Commonwealth and Colonial Law, London: Stevens, 1966, p. 543; Morris, H.F., and Read, J.S., Indirect Rule and the Search for Justice: Essays in East African Legal History, Oxford: Clarendon Press, 1972, Chap. 2 et seq.

2 The only expections to this were the colonies where Roman-Dutch law was to apply. These are mentioned below, note 18 .

3 Allott, AN., Essays in African Law, London: Butterworths, 1960, Chap. 7; Id., "The Future of African Law", in: Kuper, $H$., and Kuper, $L$. (eds.), African Law: Adaption and Development, Berkeley and Los Angeles: U of Califomia Press, 1965. pp. 216-240; Roberts-Wray, K.O., op. cit., pp. 533-534.

4 Allott, AN., op. cit. (1960), ibid. 
It has been argued elsewhere that this historical experience may assist to uncover the complexity and variability in theory and practice of "recognition" of customary laws. 5 This note concerns the influences operating upon official policymaking when legislation first provided for recognition. A more adequate understanding of the determinative factors of this aspect of British colonial policy must await the completion of more archival research on the decisionmakers' debates inter se. 6 Here certain influencing factors are considered, primarily the previous colonial legal history and contemporary legal theory. Greater influence may have been carried by arguments about the likely political and social effects of the alternative available decisions, advanced in relation to policy such as the facilitation of trade, the promotion of European social values, or the suppression of opposition to colonial rule. Nevertheless, some interim conclusions will be suggested.

By "indigenous laws" is meant the laws followed in practice by indigenous groups. By indigenous groups is meant all groups which were already inhabitants of African colonial territories when they were colonised. It is unnecessary to discuss questions about which groups had been there longer than others and so might have a better claim to be "aboriginal". In the territories in question most indigenous laws are appropriately referred to as "customary laws", the exceptions being the religious laws which are in some territories socially accepted laws.

\section{The Question}

Why did the British adopt the peculiar policy of recognising indigenous law in all their African colonies from the beginning of the colonial period? The question requires discussion of the colonial power's perceptions, objectives, and view of historical

5 See e.g. Woodman, GR., "Customary Law, State Courts, and the Notion of Institutionalization of Norns in Ghana and Nigeria", in: Allott, A., and Woodman, G.R., (eds.) People's Law and State Law: the Bellagio Papers, Dordrecht: Foris, 1985, pp. 243-163; id., "How State Courts Create Customary Law in Ghana and Nigeria", in: Morse, B.W., and Woodman, G.R. (eds.), Indigenous Law and the State, Dordrecht: Foris, 1988, pp. 181-220. A conceptual analysis of forms of "recognition" is attempted in Morse, B.W. and Woodman, G.R., "Introductory Essay: the State's Options", ibid., pp. 5-24.

6 Research in this and related fields is reported in: Seidman, RB., "A Note on the Construction of the Gold Coast Reception Statute", Joumal of African Law, 13 (1969), pp. 45-51 (which concerns the decision as to the wording of a provision for the reception of English law); Morris, H.F., and Read, J.S., op. cit. (which concentrates attention on a period subsequent to the initial constitution of the legal systems); Mugambwa, J., The Legal Aspects of the 1900 Buganda Agreement Revisited, Joumal of Legal Pluralism, 25 \& 26 (1987), pp. 243-274 (which again concentrates on a subsequent period). 
development. This is not to imply that these had a superior truthfulness or value to those of the colonised peoples. 7

It might be thought peculiar to view this practice as "peculiar". What could be more natural and normal than a foreign power obtaining political domination should preserve the currently operative laws of an indigenous people, at least for the regulation of relations between indigenes? Students of indigenous laws will react sceptically to that counterquestion. The policy which was followed by the British in Africa was unusual in the general history of indigenous laws in societies colonised by Europeans. This "peculiarity" will be summarised.

The colonising European powers imposed their own governmental structures and laws in colonised territories. They often tolerated the continued existence of indigenous laws, but most did not require their own legal systems to give effect to them. The British themselves in many colonies outside Africa, most notably in the Americas and Australasia, established legal systems which denied the validity of indigenous laws, or relegated them to ill-defined, marginal fields of operation. 8 The British African policy was thus, seen in a wider context, peculiar. It will be suggested nevertheless that it was by no means unique, and that the established practice of certain British colonial governments predisposed the decisionmakers to adopt it in Africa.

7 Elsewhere attempts have been made to examine aspects of the historical development of legal pluralism in Africa in terms of both views: Woodman, G.R., "Unification or Continuing Pluralism in Family Law in Anglophone Africa: Past Experience, Present Realities, and Future Possibilities", Lesotho Law Joumal, 4, 2 (1988), pp. 33-79; id., "Conflict, Agglomeration, Integration and Unification of the Land Tenure Laws of Ghana", Jahrbuch für af rikanisches Recht, forthcoming.

8 On the North American colonies which formed the USA, see: Cohen, $F$., Handbook of Federal Indian Law (1982 ed.), Albuquerque: U. of New Mexico Press, Durham, W. Cole, Jr., "The Aboriginal and Comparative Law: a United States Perspective", Amrican Joumal of Comparative Law, 34 (Supplement), 1986, pp. 1-28, republished with minor amendments as "Indian Law in the Continental United States. An Overview", Law \& Anthropology, 2 (1987), pp. 93-112. On Canada, see: Morse, B.W., "Aboriginal Peoples and the Law", in: Morse, B.W. (ed.), Aboriginal Peoples and the Law: Indian, Metis and Inuit Right in Canada, Ottawa: Carleton U Press, 1985, pp. 1-15; Id., "Indigenous Law and State Legal Systems: Conflict and Compatibility", in: Morse, B.W., and Woodman, GR. (eds.), op. cit., pp. 101-120. On the former British territories of the Caribbean, see Patchett, K.W., "Reception of Law in the West Indies" (1973) Jamaica Law Joumal 17-67. On Australia, see: The Law Reform Commission, The Recognition of Aboriginal Customary Laws, Australian Law Reform Commission Report No. 31, Canberra: Australian Govemment Publishing Service, 1986, Vol. 1, Chaps. 4-5. On New Zealand, see: Adams, P., Fatal Necessity, Auckland: Auckland U. Press and Oxford U. Press, 1977; Russell, R.M., "Legal Pluralism in New Zealand over the last One Hundred and Twenty Three Years", paper presented to the conference of the Commission on Folk Law and Legal Pluralism, Zagreb: August 1988, citing also McHugh, P.G., The Aboriginal Rights of the New Zealand Maori at Common Law, Ph.D. thesis, Universitiy of Cambridge. 


\section{The Historical Context}

The colonial legal systems were designed by officials of the Colonial Office. Decisions such as these are likely to be conditioned by the decisionmakers' perceptions of the social fields in which the new systems are to function. However, decisionmakers in a new field may also bring with them a body of policies developed in analogous areas of activity. Such as ready-made policies are especially likely to be influential in planning for a relatively unknown field.9 Legal doctrines determining the laws applicable in British overseas territories were developed in the common law over several centuries, and set forth forwards the end of the eighteenth century in judgements of the English courts and texts. 10 The rules relevant to a territory differed according to the mode by which it had been acquired.

Territory acquired by settlement was that which had had no system of law until British subjects settled there. The category included uninhabited territory, and territory inhabited by peoples regarded as so uncivilised that they could not be said to have laws. Here English law applied, on the ground that the settlers carried it with them as their personal law. In this category were much of the territory of the colonies of North America and the Caribbean, the whole of Australia and much of New Zealand. In categorising most of these territories as uninhabited, or the indigenous inhabitants as uncivilised peoples without laws, the colonisers were setting in train histories which have evoked bitter criticism, and which

9 "Ultimate authority over a colony is exercised by people who are not members of that society and who, for the most part, have never visited that society and know very little about it. Consequently, the colonial policy of the imperial ruler is determined not so much by the realities of the colonial situation as by metropolian political considerations that are extemal and irrelevant to the colonial society." Thompson, L., "Historical Perspectives of Pluralism in Africa", in: Kuper, L., and Smith, M.G. (eds.), Pluralism in Africa, Berkeley and Los Angeles: U. of California Press, 1969, pp. 351371, p. 352. This would seem to be largely accurate as to the policies now in question. It may be added that, in the absence of pressing "metropolitan political considerations", the adoption of past colonial policies may be attractive.

10 General accounts of this law are given in: Forsyth, W., Cases and Opinions on Constitutional Law, London : Stevens \& Haynes, 1869, Chap. I; Roberts-Wray, K.O., op. cit., Chap. 11; Elias, T.O., British Colonial Law: a Comperative Study of the Interaction Between English and Local Laws in British Dependencies, London: Stevens, 1962, Chaps. 1-3, 5, 6; Halsbury's Laws of England, 4th ed., Vol. 6, London: Butterworths, 1974, "Commonwealth and Depencies" , Part 5. A particularly instructive study of a numerous and varied set of instances is: $K . W$. Parchett, op. cit. The principal textbook statement in the late eighteenth century was Blackstone, $W$., Commentaries on the Laws of England (12th ed., Christian, E., ed.), London: T. Cadell, 1793, I, pp. 106-7. The text of the first edition (1765) had stated the same rules, with less elaboration. By the time of the 12th ed. the author had amended it to incorporate the qualifications expressed in Campbell v. Hall (1774) 98 E.R. 1045, 20 State Tr. 239. The general, basic rules stated below all to be found in these two authorities. Forsyth, $W$., op. cit., prints some relevant opinions of law officers of the Crown, the earliest of which is dated 1720 . 
today see strident claims by the indigenous peoples for recognition of their laws and the land rights which they confer.

In territory acquired by conquest or cession the previous laws remained in force, except in so far as they were contrary to the fundamental principles of English law, 11 until lawfully abrogated. The present importance of this rule was that it entailed the recognition of indigenous laws. However, its applicability was not always clear because the distinction between the two categories of territory might be blurred. Once a territory had been acquired by cession or conquest there was likely to be settlement in some localities by Brititsh subjects, who might claim the application to them of English law.

An extreme instance of a mixture of categories arose if on conquest the territory was entirely vacated, and then settled by British subjects. In that case, the law applicable was apparently English law alone. 12 This particular situation was rare, but its express discussion opened an important possibility. It became arguable that, in a conquered or ceded territory, English law was applicable in any area which was settled by British, even an area where the settlers became only a part of a population.

At the other extreme was the instance where by treaty British subjects settled among the more numerous, previously settled population. This occurred in parts of India. A comparison could be drawn with instances where British subjects settled in another European country by permission of the government, and without cession of territory. It was clear that there the settlers would be govnered by the laws of the host people. However, in India English courts were established to apply English law in disputes between British settlers. This was explained on the grounds that the settlers did not intermix and become part of the general population, and the local rulers permitted the settler communities to govern themselves according to their own laws.13 Here, again, there was a basis for developing a policy of recognising indigenous law, but applying English law in areas settled by British subjects.

11 Early statements of this rule charactarise the excluded laws in terms such as "against the laws of God and of nature contained in the Decalogue". An exclusion of laws on the ground of their nonChristian character was emphatically disapproved in Campbell v. Hall.

12 This was suggested to be the case with Jamaica, which was acquired by conquest from Spain but was vacated by the Spaniards: Campbell v. Hall. On Jamaica, see further Patchett, K.W., op. cit. pp. 21-22. Such extensions of the rules as to settlement are noted by Roberts-Wray, K.O., op. cit., pp. 542-43.

13 This explanation appeared in its fullest form in Advocate-General of Bengal v. Ranee Sur. Dossee (1863) 15 E.R. 811, which relied upon the judgment in "The Indian Chief" (1801) 165 E.R. 371 (sic: the date 1880 is clearly as misprint). It accords with the terms of the earliest licence for British settlement, given by the Mughal Emperor in 1615, for the settlement at Surat: Jain, M.P., Outlines of Indian Legal History, Delhi, 1952, pp. 4-5, 6-7. 
These developments resulted in pluralist systems of law. A further development followed from the notion of personal laws. This suggested that a pluralist legal system might be that in which the respective spheres of English and indigenous laws were not territorial areas, but categories of persons: a system in which English law applied to settlers, and indigenous law to indigenes. That distinction was affected by a tendency, present from the beginning, to extend English law to indigenes who were employees of the British administration (in India, of the East India Company), whose had commercial dealings with British, or whose conduct showed an intention to observe English law. Thus English law became entrenched as the law of a significant section of the indigenous population, not merely of a small and possibly transient group of settlers. 14

These rules applied only so long as a competent legislative authority did not intervene. When such intervention occurred, it was usually in the form of an express enactment of the previous scheme, clarified, and sometimes amended. Thus in India, as the British extended their administrative power beyond the narrow initial jurisdiction over British settlements, they established courts with increasingly wide jurisdiction over persons and causes. These courts were required to apply English law between settlers, as hitherto, and indigenous Hindu and Moslem laws to relations between indigenes which previously had been governed by those laws. 15

These general principles continued to be followed in the early nineteenth century in Burma.16 The practise was then extended to Africa. Thus a court created on the Gold Coast

14 All instances of settlement, whether it was the basis of acquisition of territory or a process which occurred within territory already acquired by other means, raised disputable issues of territorial boundaries. The area of application of the laws introduced or endorsed by the acquiring power was in principle the area settled in fact, but the boundaries of that area were likely to be vague. Later, when particular laws continued to be applied on a territorial basis, difficulties were frequently cut through by a binding legislative specification of boundaries. When the territorial bases of application were replaced by personal bases, different difficulties arose, whether the distinction between persons was based upon race, religion, mode of life, or other.

15 Jain, M.P., id., passim. See e.g. the Act of Settlement, 1781, which, confirming established practice, conferred on the Supreme Court of Fort William jurisdiction over all actions against inhabitants of Calcutta, and provided that in large classes of defined cases Moslem or Hindu law was to be applied: op. cit., pp. 114-115. These forms of provisions were applied by repetition or express reference to the courts of all the Presidency towns. The British operated simultaneously a second and separate judicial system, the Mofussil courts, in which also indigenous laws were applied, but on the basis that judicial power had been more directly conferred on them by local rulers. On the resultant legal system in India, see also Gledhill, A., The Republic of India, The British Commonwealth: the Development of its Laws and Constitutions, No. 9 (2nd ed.) London: Stevens, 1964. See e.g. the terns of the proclamation issued immediately after the first war with Britain, 1825, which promised to administer justice to the people "according to their own established laws": Furnivall, J.S., Colonial Policy and Practice: A Comparative Study of Burma and Netherlands India, Cambridge: Cambridge University Press, 1948, p. 30, which, however, notes also certain 
in 1844 was required to observe and apply "such of the local customs of the said Countries and places as may be compatible with the principles of the law of England...", and in default of such, to apply English law.17

The colonial officials charged with designing legal systems for the African colonies later in the century thus had to hand operative examples of long-standing practise in comparable territories. This practise was generally to import English law for application to British settler communities, but to recognise existing indigenous law. The of ficials were not required to continue the practise. But their mandate could be fulfilled most simply and uncontroversially by drafting legislation which provided an authoritative and clarified version of the rules already in practise. This they did, continuing in effect the policies already long inherent in existing colonial legal systems. 18

\section{The Theoretical Context}

Those who framed the colonial legal systems were subject also to the influence of accepted British views of the necessities and proprieties of a legal system. It was inevitable that they should come to their work with some concept of the essential nature of a legal system.19

qualifications in respect of commercial matters. See also op. cit., pp. 131-34, where it is shown that in the last quarter of the nineteenth century and subsequently the policy was to apply indigenous law, although in practice there was great difficulty in doing so, and the British administration is said to misconceived the nature of indigenous law (e.g. at pp. 30-31, 131-34, 245).

17 Gold Coast Jurisdiction Order-in-Council, 3 Sept. 1844, Colin W. Newbury, British Policy Towards West Africa: Select Documents 1786-1874, Oxford: Clarendon Press, 1965, p. 555. See also the semi-official exercise of jurisdiction in the years immediately prior to that Order-inCouncil, when the British possessions on the Gold Coast were govemed by the Committee of Merchants: GE. Metcalfe, Maclean of the Gold Coast, London: Oxford U. Press, 1962, pp. 16878. See generally on this period of development, Allott, AN., op. cit. (1960), pp. 99-103.

18 While the clearest evidence of their policies is at present the courts statutes themselves, some research provides additional evidence. See e.g. Morris, H.F., and Read, J.S., op. cit., pp. 14-15, footnotes 32, 33. The partial exception in some territories of Southem Africa, where Roman-Dutch law, not English law, was the imported law, is consistent with the general pattem. In some of these areas, Roman-Dutch law was already generally in force when Britain acquired jurisdiction, as the law of previously settled Europeans. It remained in force after cession by the settler regimes, as part of the existing law. In the other areas Roman-Dutch law was subsequently imposed when they were colonised from the existing Roman-Dutch areas.

19 This section mentions several theoretical views which were widely accepted in the legal profession at the time the African colonial legal systems were designed. An altemative route of inquiry would be to examine the more particular views expressed by lawyers as they dealt with issues of legal policy in Britain at the time. Such an investigation is presented in Arthurs, H.W., "Without the Law": Administrative Justice and Legal Pluralism in Nineteenth-Century England, Toronto and Buffalo: U. of Toronto Press, 1985. Arthurs notes briefly the relevance of the views of Austin and Dicey: op. cit., pp. 183-84. 
Ultimately theoretical arguments would have been discarded in the face of practical necessities, but the colonial policy-makers may have been relatively isolated from particular local circumstances. 20

The most influential theory of law in late Victorian England was that of John Austin, derived with some amendments from that of Jeremy Bentham.21 Four interrelated propositions of these writers' analyses need mention. Each tends to deny either that indigenous peoples' law is genuine law or that it should be recognised by state law, or both. First, all laws emanate from and are enforced by institutions of the state. 22 Hence the laws of an ethnic group are not laws "properly so called". This conclusion is not contradicted by legislation providing that indigenous laws are to be recognised by the state, thereby (according to this view) transforming them into laws. But by denying them per se the status of laws it makes recognition less acceptable than would be the recognition of existing laws properly so called, such as the laws of another sovereign state.

Secondly, all laws are legislation, being direct or circuitous, express or tacit commands or the lawmaker. Hence again customary laws cannot as such be laws properly so called.23

Thirdly, a state is a single society, and is governed by a body of laws which preferably are generally applicable to all subjects. 24 Even if for practical legislative purposes a colony is conceived of as a separate society, this proposition is opposed to pluralism within that society's legal system. Thus, if the laws of the colonising power are imported, indigenous laws should not also be recognised.

20 Cf above note 9.

21 Bentham, J., A Fragment on Govemment (rev. ed. by Bums, J.H., and Hart, H.L.A.), Cambridge: Cambridge U. Press, 1988 (original text first published 1776); id., Of Laws in General (Hart, H.L.A., ed.), London: Athlone Press, 1970 (not published in the author's lifetime, but probably known in substance to his followers, including Austin; hereafter "OLG"); Austin, J., The Province of Jurisprudence Determined (rev. ed. by Hart, H.L.A.), London: Weidenfeld and Nicolson, 1954 (original text first published 1832).

22 The source of all law is the sovereign person or body of persons in a state: OLG, pp. 1, 18; Austin, J., op. cit., p. 193.

23 Austin, J., op. cit., pp. 30-32, 140-44, 162-64. Bentham, OLG, Chaps XIII and XV, argues similarly; but more directly relevant is Bentham, J., A Comment on the Commentaries and a Fragment on Govemment (rev. ed. by Bums, J.H., and Hart, H.L.A.), London: Athlone Press, 1977, pp. 308-9, part of the previously unpublished "Law of Nature: Altemative Draft", which also asserts the possibility of "conversion" of custom into law by state recognition.

24 Bentham, J., op. cit., Chap. 1; Austin, J., op. cit., pp. 194-195; OLG, pp. 160-162 (on the generality of "complete laws"). Cf. Austin, J., op. cit., pp. 18-23, holding that the necessary general nature of laws means only that each law should refer to a class of acts, and not that it must necessarily be addressed to more than one person. 
Fourthly, laws are commands specifying conduct, and therefore they have a high degree of clarity and precision, and are capable of relatively automatic, inflexible application. 25 This implies opposition to the recognition of customary laws, which have frequently been viewed by external observers as unclear and imprecise, and even by sympathetic participant observers as liable to be applied with great flexibility. 26

That these views remained dominant into the latter half of the century appears from the first major work of Dicey.27 $\mathrm{He}$ asserted that the two fundamental features of English constitutional law (which he lauded) were the supremacy of the central government throughout the country, 28 and the rule of law, the elements of which required that all citizens should be subject to the "ordinary" law and no other. 29

In contrast Maine took a more receptive view of customary laws. $30 \mathrm{He}$ regarded custom, manifesting the legal sense of a people at an early stage of development, as the precursor and part source of the more developed law which emerged in progressive societies. $31 \mathrm{His}$

25 OLG, p. 1, Chap. V; Austin, J., op. cit. pp. 13-14. So all complete laws were imperative, or penal: OLG, Chap. XVI; Austin, J., op. cit., ibid. Laws such as those of proberty or contract were analysed either as elaborate definitions of terms used in penal rules (OLG, Chap. 16), or as imperatives which threatened the sanction of nullity for non-compliance (Austin, J., Lectures on Jurisprudence or the Philosophy of Positive Law (4th ed.), London: John Murray, 1879 (rev. Campbell, J.), Lecture 23).

26 Such views, allied with the Austinian notion of law, produced assertions of the difficulty or impossibility of applying indigenous laws in state courts in the absence of codification, some long before the African legal systems were designed. See e.g. the series of complaints by the Commissioner of Tenasserim, Buma, in the 1820s, noted Furnivall, J.S., op. cit., p. 31.

27 Dicey, A.V., Introduction to the Study of the Law of the Constitution, 10th ed., London: Macmillan, 1960 (original text first published 1885).

28 Ibid., p. 183. A substantial part of Dicey's preceding discussion of the legislative supremacy of Parliament (pp.94-121) is concemed with India, and there are references to the laws of other colonies, and but there is not one mention of indigenous laws.

29 Ibid., Chap. IV.

30 Maine, H.S., Ancient Law (1st ed. with notes by Pollock, F.), London: John Murray, 1906 (original text first published 1861); Id., Village-Communities in the East and West (3rd ed.), London: John Murray, 1876 (original text first published 1871; Id., Lectures on the Early History of Institutions, London: John Murray, 1875.

31 See e.g. Id., Ancient Law, pp. 10-12. This notion had, of course, been developed earlier in Savigny's powerful polemic against the codification proposal of Thibaut: Savigny, F.C. von, Zum Beruf unserer Zeit für Gesetzgebung und Rechtswissenschaft, 1814. Austin devoted time in his lectures to a detailed, comprehensive and emphatic rejection of Savigny's arguments: Austin, J., Lectures on Jurisprudence, pp. 698-704 (and see also id., "Notes on Codification", in: op. cit., pp. 1056-74, at pp. 1072-73). However, for some of the writers on these disputes "customary law" meant juristic custom, or case law, and the debates became arguments about the respective lawmaking functions of the formal legislature and the judge. This seems to be the case as to some of the German writings around the same time, e.g. Hugo, "Die Gesetze sind nicht die einzige Quelle der juristischen Wahrheiten", Civilistisches Magazin, 4 (1812), pp. 89-134. On the influence of 
ideas could have provided counter-arguments to those derivable from Bentham and Austin.32

However, it appears that in Britain Bentham and Austin had far more influence on legislators. The utilitarian programmes for reform which Bentham inspired were manifest in the radical nineteenth-century reforms of English law. Admittedly, the drive towards codification which was part of those programmes 33 failed eventually to achieve much legislative success in England. But, significantly for the present purpose, it resulted in the enactment of a series of codes of common law in India.34 One result was that a set of operative codes was ready for adoption in any colonial jurisdiction where English law was to be applied.

\section{Interim Conclusions}

In the construction of colonial legal systems, some decisions were consistent with both of these influences. The decision to enact legislation setting up a Supreme Court in each colony, conferring on it jurisdiction over all persons and all causes, and requiring it to apply English law, accorded with colonial practise and could also have been a step towards the creation of a legal system according with positivist theory. The subsequent trend towards the enactment of codes in place of the imported case-law similarly accorded both influences. 35

Savigny's ideas on British legal thought in the mid-nineteenth century, see Stein, P., Legal Evolution: the Story of an Idea, Cambridge: Cambridge U. Press, 1980, pp. 72-86.

32 See e.g. his statement that "the further we penetrate into the primitive history of thought, the further we find ourselves from a conception of law which at all resembles a compound of the elements which Bentham determined" (op. cit., p. 7). Id., Village-Communities in the East and West, is based on Maine's experience in India, and notes that the discussion is against a background of an importation of English law combined with a recognition of indigenous law. The two schemes of thought were not necessarily opposed. Bentham by implication, and Austin expressly limited their analyses to "the ampler and maturer systems" of law: Austin, J., "On the Uses of the Study of Jurisprudence", in: Lectures on Jurisprudence or the Philosophy of Positive Law, pp. 1106-1128, p. 1108. Maine wrote of the historical development of legal systems from their earliest stages, and much of what he said as to the latest stages was compatible with the implied prescriptions of Bentham and Austin. Nevertheless, the two schemes provided arguments which could be deployed to support opposed policies.

33 A large part of Bentham's writings consists of proposals for codes: see e.g. Bentham, J., Theory of Legislation (from the French of Dumont, E., trans. Hildreth, R., new ed.), London: Kegan Paul, 1911. On Austin in this respect, see above note 31.

34 Jain, M.P., op. cit., Chap. XIXB.

35 Codes of criminal law, most of them derived from Queensland, were enacted in all territories. For other areas of law, the Indian codes were widely adopted in the initial colonial period in Africa: see e.g. Morris, HF., and Read, J.S., op. cit., Chap. 4. 
However, the conferment of unlimited jurisdiction on the Supreme Courts forced a choice between the policies. It brought within the courts' jurisdiction multitudes of relations which until then had been governed by indigenous laws. The implications of positivist theory required that these relations should thereafter be determined by the one imported law. The decision that the Supreme Courts were to apply indigenous law, and the further decision to incorporate native courts into the state legal system, marked a clear rejection of the implications of positivist legal theory. 36,37

It is hardly surprising that prevalent legal theory in late nineteenth century Britain was opposed to the recognition of indigenous law. Officially accepted theory emerges from and reflects dominant social practise, and, while it may provide argument for some degree of change, it is unlikely to argue for both fundamental and extensive change. Theory which emerges and is acceptable in a society with a unitary legal system is likely to regard pluralism in state law as undesirable and even impossible. Legal theory from an industrialising, capitalist nation-state with a powerful legal profession is unlikely to conclude that African customary laws should be recognised.

These conclusions are still inherent in most of the more widely discussed and accepted legal theory in the industrialised nations today. Their validity needs to be questioned on scientific grounds. It can further be argued that in multicultural societies unitary, imported

36 Recognition was subject to an exception for laws which were repugnant to "natural justice, equity or good conscience", or some similar criterion. It is striking that this was substantially the same exception as that in the common law on the continance of pre-colonial laws, already mentioned. In the absence of further detailed research it remains uncertain how far regard for the historical experience was a cause of the rejection of the policies implied by accepted theory. It is also unclear how far the decisionmakers were aware of the then accumulated experience of operating such provisions. Had they known much of this, they might have found grounds to hold that the objections implied in positivist legal theory were justified: that it was impossible to recognise customary laws on the basis that they were existing laws, and that the effect of "enforcing" them in colonial state courts was, if not the "invention" of something totally novel, at least the "creation" of new state laws out of the material of prior, authentic, non-state laws. This effect of recognition of indigenous law in Africa has been explored in the papers cited above, note 5. For an example of similar experiences elsewhere prior to recognition in Africa, see Furnivall, J.S., op. cit., above, note 16.

37 The later policy of indirect rule entailed a reversal of the decision as to the jurisdiction of the Supreme Courts. Measures were enacted to prevent these courts from hearing cases which would be determined by customary law, although their constituting statutes were never amended to remove customary laws from the laws which they were required to apply. This occurred, for example, on the amalgamation of Northem and Southem Nigeria, when the policy of indirect rule was extended from Northem Nigeria, where it had been already put into effect, to Southem Nigeria, where the colonial courts had initially been given jurisdiction in all cases. See e.g. Perham, M., Native Administration in Nigeria, London: Oxford U. Press, 1937, pp. 67-69. However, indirect rule also entailed a firm entrenchment in the state judicial system of the native courts, applying customary laws (although it was liable to be a quite distinct part of the system, without even a relation even by way of review to the Supreme Court). 
laws necessarily fail to satisfy, in relation to indigenous peoples, the evaluative criteria, such as adherence to due process or equal treatment - of those imported laws. 38 But it may prove impossible to overcome the opposition to state recognition of indigenous law if the debate centres on the theoretical justification for maintaining the character of existing unitary state legal systems. To argue for the true legal nature of customary law, and the moral value of legal pluralism, is to fight the theoretical objection to pluralism on its chosen ground. It is possible that today those who advocate the recognition of indigenous laws might gain more success if they demonstrated from history that that which they sekk is a type of state legal system which has long been common, and has functioned without insuperable practical difficulty. 39

38 This form of argument was advanced, for example, at the initiating conference of the Commission on Folk Law and Legal Pluralism: see Woodman, G.R., "Part V. Introduction", in: Allott, A.N., and Woodman, G.R. (eds.), op. cit., pp. 277-80.

39 A consideration of the experience of state recognition of indigenous laws might also incite questions as to whether such recognition nècessarily advances the interests of indigenous peoples. It is arguable that in colonial history recognition was a means of exploiting indigenous peoples' productive capacities for the benefit capitalist modes of production. (See e.g. the literature mentioned in Woodman, GR., op. cit. above note 7 (1988), pp. 50-51, and op. cit. ibid. (forthcoming). But that is outside the purview of the present inquiry. 


\section{ABSTRACTS}

\section{The Aboriginal Peoples of Canada and their Rights under Canadian Constitutional \\ Law}

\section{By Stephan Marquardt}

The new Canadian Constitution, which came into force in 1982, makes specific reference to the rights of the aboriginal peoples of Canada. The constitutional recognition of their rights is the reflection of their special status in the Canadian legal and political system. This special status raises a number of complex legal and political issues.

The new constitutional provisions relating to aboriginal rights add to this complexity. The central issue is whether the aboriginal peoples have an inherent right to self-government protected by the Constitution and what the legal and political implications of this right are. The article attempts to illustrate the main aspects of this issue.

The Peculiar Policy of Recognition of Indigenous Laws in British Colonial Africa. A Preliminary Discussion

\section{By Gordon R. Woodman}

The British provided that the courts in their African colonies should apply both English law and indigenous laws. This recognition of indigenous laws within pluralist state legal systems may afford insights into issues concerning the recognition of indigenous laws. Two of the influences possibly operating upon the British decisionmakers are discussed.

According to existing English law, in overseas territories acquired by settlement, English law applied. In territories acquired by conquest or cession, the previously existing laws, including indigenous laws, continued in force. However, in the latter territories English law sometimes applied to localities subsequently settled by British, or to the relations of British settlers or westernised indigenes.

Legal theory in Britain presented arguments as to the essential features of a legal system. These tended to be incompatible with the recognition of customary law. 
The policy-makers adopted the pattem provided by existing English law and impliedly rejected the theoretical objections. An interim conclusion is that the view of operative legal systems in which indigenous laws are recognised may be a persuasive factor in overcoming theoretical objections to such recognition.

\title{
Ethnic Conflict in States of the Third World
}

\author{
By Jakob Rösel
}

The following paper explores the emergence of frequent and radical ethnic conflict in the postcolonial states along three perspectives: the colonial heritage, the impact of an accelerated process of modemization and the ambiguous consequences of democratization. Colonial rule preserves and often enhances a delicate system of limited, polyethnic "incorporation into the market place and into the state". After independence processes of economic, cultural, social - modemization of ten weaken, destroy or transform those ethnic "markers" - language, religion, myth of origin, area of settlement - by which different groups traditionally defined themselves. Modemization thus gives rise to a tendency to idealize or even reconstruct a group's ethnic identity and cultural heritage. At the same time, confronted with the challenge of administrative centralization, rapid urbanization and the emergence of central, "national" markets, ethnic groups solidarity now serves the new functions of defending the group's economic interests, of organizing the migration and adjustment to the expanding cities or of securing access to new markets or the growing apparatus of state. It is the transformation of an ethnic lobby into an ethnic voting block or party, that finally leads to the politization and radicalization of ethnic conflicts. Proportionate to the extent that ethnic cleavages become inscribed into the party structure these cleavages can lead to the complete political segmentalization of the electorate and to the dissolution of the precarious democratic framework of the postcolonial state. 